\title{
DOUTRINA
}

\section{O SISTEMA CONSTITUCIONAL BRASILEIRO E AS RECENTES INOVAÇÕES NO CONTROLE DE CONSTITUCIONALIDADE (LEIS No 9.868, DE 10 DE NOVEMBRO E № 9.982, DE 3 DE DEZEMBRO DE 1999).}

\section{ManOel GonÇALVes FerReira Filho*}

I. Introdução - II. A significação do controle de constitucionalidade para o sistema constitucional - III. O controle de constitucionalidade como um controle de supra-legalidade - IV. O controle de constitucionalidade como um controle de legitimidade - V. $O$ caráter do controle de constitucionalidade no direito brasileiro - VI. O controle de constitucionalidade na Constituição de 5 de outubro de 1988 - VII. A regulamentação legal da ação direta - VIII. A regulamentação da "argüição de descumprimento de preceito fundamental" decorrente da Constituição - IX. Observações finais

\section{Introdução}

1. O complexo sistema de controle de constitucionalidade que prevê a Constituição vigente sofreu há pouco o impacto de duas leis que vieram regular, uma, o processo e o julgamento, perante o Supremo Tribunal Federal, da ação direta de inconstitucionalidade e da ação direta de constitucionalidade, outra, a argïição de descumprimento de preceito fundamental da Constituição. São elas as Leis $\mathrm{n}^{2} 9.868$, de 10 de Novembro e $\mathrm{n}^{2}$ 9.982, de 3 de Dezembro de 1999.

2. A importância de tais leis avulta porque tocam no subsistema da Constituição que garante todos os demais, qual seja o de controle da constitucionalidade dos atos ou omissões dos Poderes constituídos. Realmente, esta é a condição da supremidade

* Professor Titular de Direito Constitucional da Faculdade de Direito da USP. Doutor honoris causa da Universidade de Lisboa. Doutor pela Universidade de Paris. Ex-Professor visitante da Faculdade de Direito de Aix-en-Provence (França). Membro da Comissão Executiva da Association Internationale de Droit Constitutionnel - AIDC. Presidente do Instituto Pimenta Bueno - Associação Brasileira dos Constitucionais. 
da norma constitucional, portanto, da valia (político-jurídica) da própria Lei Fundamental.

Com efeito, tocam elas em aspectos fundamentais desse controle. Refletem mudanças quanto ao significado desse próprio controle no sistema constitucional, e, portanto, o papel ou função do Supremo Tribunal Federal, enquanto guarda da Constituição. Mais ainda, importam em modificação na maneira de conceber o efeito da desconstituição do ato inconstitucional, o que revoluciona concepção tradicionalmente assente na doutrina e na jurisprudência brasileiras sobre a natureza de tal ato.

\section{A significação do controle de constitucionalidade para o sistema constitucional}

3. O controle de constitucionalidade é a garantia sine qua non da imperatividade da Constituição. Onde ele inexiste ou é ineficaz, a Constituição perde no fundo o caráter de norma jurídica, para se tornar um conjunto de meras recomendações cuja eficácia fica à mercê do governante, mormente do Poder Legislativo. Ao contrário, quando não só é previsto na Carta, mas tem meios de impor-se efetivamente, esta é a lei suprema, a que todos os Poderes têm de curvar-se. Assim sempre foi nos Estados Unidos da América, onde, graças a Marshall, o controle cedo se impôs, como ainda hoje se impõe.

Ao invés, às vésperas da Segunda Guerra Mundial, na Europa em que esse controle inexistia (apesar das tentativas tcheca e austríaca, inspiradas em Kelsen), uma onda de ceticismo depreciava as Constituições, "leis" sem valor jurídico, impunemente desobedecidas pelos Poderes constituídos. Hoje, porém, com o desenvolvimento da justiça constitucional nos países europeus, a atitude se modificou; a Constituição é lei, e a suprema das leis.

Há, entretanto, grande diferença entre o sistema "americano" de controle e o sistema "europeu", diferença esta que não está apenas no aspecto procedimental, ou mesmo processual. Ela reflete duas visões diferentes do que significa esse controle para o sistema constitucional, importa em duas posições a propósito do próprio ato inconstitucional.

\section{III. $O$ controle de constitucionalidade como um controle de supralegalidade}

4. Recorde-se o que todos sabem. O controle de constitucionalidade teve a sua primeira manifestação nos Estados Unidos no caso Marbury versus Madison, julgado em 1803, pela Suprema Corte.

Avultam nessa decisão alguns pontos, habilmente combinados pelo grande jurista (e homem de Estado) que foi Marshall, então Presidente desse Tribunal. Lembre-se os que interessam ao ponto em estudo: 
$1^{9)}$ A apreciação da constitucionalidade - ou seja, da adequação de uma lei ou ato infraconstitucional à Constituição - está na esfera normal de atuação do Judiciário, visto que este sempre tem de, para julgar um litígio, determinar qual a norma a este aplicável. Na verdade, a determinação da constitucionalidade, ou não, de um ato infraconstitucional, é, desse ângulo, a solução de um conflito de leis: o conflito entre a norma constitucional e a norma infraconstitucional.

$2^{\circ}$ ) Pela lógica, em razão da hierarquia das leis, a norma da Constituição deve prevalecer sobre a norma infraconstitucional. Em consequiência, o juiz deve afastar a regra inferior contrária à Constituição e aplicar ao caso a regra da Lei Maior, norma superior. É o mesmo que se passa quando há conflito entre uma norma legal e uma norma regulamentar, quando o magistrado afasta esta e aplica aquela.

$3^{\circ}$ ) Assim posto, o controle de constitucionalidade não se distingue do controle da legalidade de um ato qualquer em face da lei, exceto pelo fato de que o confronto se dá entre a lei (ou outro ato infra-constitucional) e a norma constitucional. $O$ controle de constitucionalidade consiste, destarte, num controle de supralegalidade.

5. Destaque-se um outro ponto, de importância capital.

A análise de Marshall implica um juízo sobre a natureza do ato inconstitucional. Dela decorre que a regra colidente com a Constituição é uma norma sem valor "null and void", é a expressão usada, que Rui Barbosa traduziu por "nula e írrita".

Várias consequiências resultam deste entendimento lógico. Uma é a de que, sendo nulo o ato inconstitucional, não pode este produzir qualquer efeito válido. Daí se infere ser insuscetível de convalidação tal ato.

Igualmente, daí se há de concluir que o reconhecimento judicial da inconstitucionalidade tem caráter declaratório. Mais, que ele há de operar necessariamente $e x$ tunc, ou seja, deve retroagir para retirar valor a tudo o que se apoiar numa norma inválida desde sua origem.

6. Nos aspectos acima ressaltados, o cerne do modelo dito "americano" que a doutrina denominou de controle incidental, ou desconcentrado.

Trata-se de um controle aberto a qualquer juiz (desconcentrado), de caráter preliminar para a solução do litígio (incidental), com o sentido restrito de uma verificação de compatibilidade com a ordem jurídica. Visando exclusivamente à solução de uma questão, opera inter partes. O seu efeito, portanto, não se estende automaticamente a outros litígios que envolvam a validade da mesma norma. Embora importe no reconhecimento da nulidade de uma norma legal, não lhe retira a eficácia.

7. Este modelo de controle escamoteia o aspecto político do controle de constitucionalidade. Trata-o como uma questão simplesmente jurídica, ou de mero procedimento jurisdicional. A tarefa do juiz é apenas a de declarar, ou seja, de reconhecer objetivamente a contrariedade entre a norma constitucional e a norma legal. Considera, em consequiência, o juiz de carreira perfeitamente apto para exercer esta tarefa simples.

Não dá a este qualquer flexibilidade de apreciação, coloca-o perante o dilema constitucional/inconstitucional, válido/inválido e inválido de modo absoluto, desde 
a origem. Ora, isto às vezes tem um efeito perverso: o Tribunal deixa de reconhecer a inconstitucionalidade, dadas as conseqüências que daí decorreriam, conseqüências estas até injustas?.

Faz questão de ignorar que este controle importa em recusar valor a ato de um dos Poderes do Estado. Mais, em negar validade à lei, editada pela representação nacional, sancionada, em regra, pelo chefe de Estado, obra, portanto, dos Poderes eleitos pelo povo. E isto em regime democrático.

8. Claro está que, sob essa aparência, não deixa de estar presente o elemento político, sobretudo porque os textos constitucionais devem ser interpretados para poderem ser aplicados. Ora, na interpretação sempre se insinuam elementos ideológicos, portanto, posições políticas.

A história da Suprema Corte dos Estados Unidos revela, porém, bem claramente como o controle de supralegalidade tende naturalmente a incorporar, de mais em mais, um elemento político ${ }^{2}$. Este foi habilmente contornado por Marshall, mas veio a se tornar manifesto na oposição da Corte a medidas de proteção social que contrariavam o laisser faire. Com efeito, a doutrina de Adam Smith, numa determinada época, parecia para a maioria de seus membros inerente à Constituição de Filadélfia. E, em tempos mais recentes, um viés libertário e igualizante se apossou da mesma, assumindo a sua jurisprudência posições extremamente favoráveis à proteção dos acusados, à integração racial, à facilitação do aborto etc., da qual ela hoje recua.

Não é por outra razão que a Suprema Corte dos Estados Unidos já foi acusada de haver implantado o "governo dos juízes".

9. Tecnicamente, ademais, não se pode negar, na atualidade, que só questões de interesse geral - político, portanto - é que são conhecidas e decididas por esse Tribunal ${ }^{3}$.

Depois do Judges Bill de 1925 praticamente não há mais questões que sobem obrigatoriamente até a Corte Suprema. Tornou-se, desde então, o provimento de writ of certiorari o caminho (estreito) por que um caso sobe à apreciação da Corte. Ora, este provimento é por ela discricionariamente deferido ou indeferido, não tendo sequer o Tribunal de justificar a recusa com uma motivação qualquer.

Um voto do Justice Vinson, em 1949, é, todavia, esclarecedor sobre o critério seguido por ela. Segundo ele, o Tribunal deve tomar em consideração somente casos que "coloquem questões, cuja resolução terá importância imediata para além dos fatos concretos e das partes envolvidas" 4 .

1 Exemplo disto ocorre no Brasil quando leis favorecem grupos de servidores públicos, violando o princípio de igualdade. Não podendo, ou não ousando, estender a todos a vantagem o Judiciário fecha os olhos para a inconstitucionalidade.

2 V. a este propósito, Bernard Schwartz, A history of the Supreme Court, Oxford University Press, Nova Iorque e Oxford, 1993.

3 Cf. Eduardo Garcia de Enterría, Reflexiones sobre la Ley y los principios generales del Derecho, Ed. Civitas, Madri, Reimpressão, 1996, p. 148 e s., que cita abundantemente fontes norte-americanas.

4 Id., p. 150, nota 74 . 
Não resta dúvida, todavia, que o sistema "americano" imprime ao controle um caráter mais jurídico do que político.

\section{O controle de constitucionalidade como um controle de legitimidade}

10. Outro sistema dito "europeu" surgiu em 1920, com as Constituições da Checoslováquia e da Áustria, em ambas os casos sob a influência das idéias de Hans Kelsen ${ }^{5}$. Entretanto, somente tomou impulso depois da $2^{a}$ Guerra, quando foram instituídas a Corte constitucional italiana na Carta de 1948, o Tribunal constitucional alemão, em 1949. Ganhou força com o Conselho constitucional francês de 1958 e se consagrou definitivamente a partir dos anos 70 , com o surgimento da justiça constitucional em Portugal (1976), na Espanha (1978), Polônia (1982), Bélgica (1983) etc. ${ }^{6}$

11. Pondo-se de lado o Conselho francês, que foge ao padrão geral, pode-se dizer que se trata de um sistema concentrado nas mãos de um órgão especial, de função jurisdicional, contudo, não integrado no Judiciário, nem composto por membros deste, mas por personalidades escolhidas fora dele. Ou pelo menos, contando com estas personalidades em número sensível.

Tal ente aprecia, em tese, in abstracto, a constitucionalidade de uma norma ou lei, tomando uma decisão incontrastável a respeito disso, obrigatória para todos, inclusive para o Judiciário. O reconhecimento da constitucionalidade ou inconstitucionalidade atinge diretamente o ato, cortando-lhe no último caso a eficácia de modo definitivo ${ }^{7}$. Assim, atinge, de imediato, todos os casos a que esse ato se aplique, mesmo naqueles em que essa questão não foi invocada.

Trata-se - insista-se - de um controle que atua sobre norma ou lei já vigente, em geral por provocação de órgão judiciário perante o qual a questão foi levantada, num litígio concreto. Tem, pois, caráter repressivo.

12. O Conselho francês atua de modo diferente, pois, se solicitarão, ou necessariamente no caso de lei orgânica, aprecia a constitucionalidade de norma em elaboração. Sua manifestação pela inconstitucionalidade obriga o legislador a alterar o projeto, para que se coadune com a Constituição. Assim opera preventivamente, pois, uma vez promulgada a lei, nenhuma contestação acerca de sua constitucionalidade pode ser suscitada.

13. Na aparência, apenas o modo e a composição do órgão que opera o controle são diferentes em relação ao sistema americano. E reforça essa aparência o fato de que, no confronto entre a norma infraconstitucional e a regra constitucional, deve dar preferência a esta.

5 Vale consultar sobre os primórdios do controle de constitucionalidade na Europa a obra clássica de Charles Eisenmann, com prefácio do próprio Kelsen, La Justice constitutionnelle et la Haute Cour constitutionnelle d'Autriche, reedição em 1986, Economica, Paris.

6 Cf. Louis Favoreu, Les cours constitutionnelles, PUF, Paris, 1986.

7 Ressalvadas possíveis atenuações, como adiante se verá. 
Mas, posta de lado a roupagem exterior, sua índole é bem diversa. Em primeiro lugar, considere-se que o órgão que o realiza não se inclui no Judiciário, nem em qualquer dos Poderes clássicos, sendo independente em relação a todos os três. Em segundo, compõe-se normalmente de pessoas que não pertencem aos quadros da justiça, escolhidas com a participação da representação popular e levando em conta os seus vínculos ou simpatias com os grupos partidários. Não têm de ser juristas (e na França podem nem ser formados em direito). Em terceiro lugar, apreciam em abstrato a norma, sem referência a casos concretos, cujas peculiaridades poderiam influir no seu ânimo.

Trata-se no mínimo de um controle político-jurídico, ao contrário do americano, jurídico-político, se se considerar a sua ênfase.

14. Ressalte-se, ademais, um quarto ponto. Podem esse controle, pelo menos na Alemanha, fugir do tudo ou nada que é o juízo constitucionalidade/inconstitucionalidade para adotar fórmulas mais flexíveis: impor uma interpretação "conforme a Constituição"; manter em vigor por certo tempo a norma inconstitucional, dando tempo para que o Parlamento a substitua por outra, essa constitucional; editar regras que supram a omissão do legislador etc.

Já se vê que, para esse sistema, o ato inconstitucional não é necessariamente nulo, devendo, todavia, serem desfeitas ex tunc as suas consequiências. Atende ele a uma lição de Hans Kelsen:

"Dentro de uma ordem jurídica, não pode haver algo como a nulidade, que uma norma pertencente a uma ordem jurídica não pode ser nula mas apenas pode ser anulável. Mas esta anulabilidade prevista pela ordem jurídica pode ter diferentes graus. Uma norma jurídica em regra somente é anulada com efeitos para o futuro, por forma que os efeitos já produzidos que deixa para trás permanecem intocados. Mas também pode ser anulada com efeito retroativo, por forma tal que os efeitos jurídicos que ela deixou atrás de si sejam destruídos ${ }^{8}$."

Com base neste entendimento, embora em princípio a norma inconstitucional deve ser anulada retroativamente, é possível graduar diferentemente o alcance de sua anulação.

15. Os caracteres apontados mostram que, no sistema europeu, a Corte constitucional muito se aproxima de uma câmara legiferante. Ao menos, tem tanto de câmara legislativa quanto de órgão judicante. Veja-se que, ao reconhecer a inconstitucionalidade, a Corte "revoga" a norma inconstitucional, embora podendo graduar o efeito, retroativo ou não, da desconstituição da mesma. Disto decorre ser a Corte um "legislador", embora negativo.

16. O caráter político desse modelo se torna flagrante quando se considera a chamada inconstitucionalidade por omissão. Consiste esta, na sua forma típica, no descumprimento de uma norma constitucional programática pelo poder que deve completá-la - o Legislativo.

Ora, o constituinte quando estabelece uma norma não executável, mormente programática, está, por um lado, comandando alguma coisa que há de ficar em

Teoria pura do Direito, trad. port., Amado, Coimbra, $2^{2}$ ed., 1962, vol. II, p.159. 
suspenso até que o poder constituído entenda oportuno regulamentá-la e assim fazê-la plenamente obrigatória. Em suma, condiciona uma regra que edita a um juízo de oportunidade.

Este juízo é por natureza político. Importa em determinar em que momento convém que aquele mandamento suspenso deva tornar-se eficaz. Envolve, portanto, um juízo de mérito, conveniência.

Ora, cabendo à Corte reconhecer a inconstitucionalidade consistente na omissão, está ela investida de um poder político de apreciação da conveniência de dar eficácia ao comando deixado em suspenso pelo constituinte.

17. Insiste-se. É evidente que este sistema europeu se apercebe do caráter político do controle e leva-o em conta. Sinaliza para um juízo mais sensível e matizado do que o "fiat justitia pereat mundus!" Sem dúvida, não dá à Corte o poder de reconhecer como constitucional o que inapelavelmente fere a Constituição, mesmo porque isto seria dar ao mesmo um poder de (no fundo) mudar a Lei Magna, um poder constituinte.

Não trata o controle de constitucionalidade como um controle de supra-legalidade, mas como um controle de legitimidade. Sim, como de legitimidade no sentido de consonância com a Carta seus princípios e seu espírito, mais do que de legalidade no sentido de conformidade com a letra do texto.

Por outro lado, a apreciação in abstracto sobre uma lei, ou parte dela, já envolve indubitavelmente mais que o simples questionamento de sua compatibilidade com a Constituição. Não são os seus efeitos que se apagam, mas é ela própria que é eliminada do rol das normas eficazes, quando sua inconstitucionalidade é declarada. Esta declaração, em tese, muito se aproxima - senão coincide - com o que seria a apreciação de uma (terceira) Câmara legislativa, em relação ao aprovado por outra (primeira ou segunda) Câmara. Isto indubitavelmente politiza o controle, pois, assume a aparência de um conflito entre Poderes.

\section{O caráter do controle de constitucionalidade no direito brasileiro}

18. O controle de constitucionalidade foi estabelecido no Brasil com a República e mesmo antes de editada a Constituição de 1891. Foi inscrito na Constituição Provisória, de 22 de junho de 1890 e prevista no Decreto $\mathrm{n}^{2} 848$, de 11 de outubro desse ano, que organizou a Justiça Federal (art. 9", parágrafo único, alíneas "a" e "c"). A Constituição consagrou-o no art. $59, \S 1^{\circ}$, "a", que regulamenta o recurso extraordinário?.

Seguiram esses documentos o modelo norte-americano. Assim, foi instituído um controle pelo Judiciário, desconcentrado, incidental. Está nisto a influência de Rui Barbosa que também impôs na prática o entendimento da doutrina e jurisprudência estadunidenses.

9 Cf. C. A. Lúcio Bittencourt, $O$ controle de constitucionalidade das leis, Forense, Rio de Janeiro, 2 ed., 1968, p. 28. 
19. Saliente-se que se adotou no Brasil também a tese da nulidade absoluta do ato inconstitucional. Ele sempre assim foi entendido (e continua sê-lo), havendo, inclusive, abundante jurisprudência do Supremo Tribunal Federal nesse sentido.

Cumpre observar, porém, que essa nulidade "retroativa" encontra limites, em nome da segurança jurídica, como os que resultam da preclusão e, mormente, da coisa julgada.

20. Igualmente, nesse controle incidental, jamais se admitiu senão o efeito inter partes da declaração de inconstitucionalidade. Este reconhecimento não afeta a eficácia da norma, que continua a poder ser aplicada.

É verdade que, desde a Lei Magna de 1934 (art. 91, IV), se prevê a suspensão dessa eficácia por ato do Senado Federal. Com efeito, reconhecida a inconstitucionalidade de norma pelo Supremo Tribunal Federal, em decisão definitiva, deve o Senado suspender a sua execução.

21. Este sistema de controle de constitucionalidade - de controle apolítico de supra-legalidade - persiste ainda hoje, adotado que foi pela Carta Magna de 1988.

Entretanto, desde 1946 vem recebendo ele aportes inspirados no sistema europeu, que tocam profundamente a significação de tal controle para o sistema.

22. Realmente, sob a Constituição de 1946, ocorreu o surgimento da ação direta de inconstitucionalidade.

Esta, na sua redação original, já previa uma representação de inconstitucionalidade para fins interventivos (art. $8^{\circ}$, parágrafo único), proposta pelo ProcuradorGeral da República perante o Supremo Tribunal Federal. O provimento desta condicionaria a intervenção federal em Estado com fundamento em violação de princípio constitucional obrigatório. Embora designada como representação, tratava-se de uma verdadeira ação que era instituída. É o que demonstrou Alfredo Buzaid, com muita precisão e clareza ${ }^{10}$.

23. Em 1965, a chamada Reforma do Judiciário, instituída pela Emenda Constitucional $\mathrm{n}^{\circ} 16$, de 26 de novembro, deu nova redação ao art. 101 , I, " $k$ ", da Constituição. Tal alínea veio então a prever, na competência originária do Supremo Tribunal Federal, processar e julgar a "representação contra inconstitucionalidade de lei ou ato de natureza normativa, federal ou estadual, encaminhada pelo Procurador-Geral da República".

A intenção do legislador constituinte era fácil de aperceber. Pretendia este instituir um controle, concentrado no Supremo Tribunal Federal, visando a norma em tese (como diz a doutrina, um controle principal e não incidental), quando a declaração da nulidade desta conviesse ao Executivo federal. Claro que este último aspecto não era explícito - qualquer um poderia, como pôde, reclamar do Procurador-Geral da República - tal "representação". Mas, em termos realistas, sendo o Procurador-Geral nomeado pelo Presidente da República e podendo ser, a qualquer momento, livremente exonerado por este, jamais atuaria ele contra as conveniências do chefe do Governo. 
Deve-se registrar que a instituição desta ação direta não foi ressentida como uma mudança no caráter do controle de constitucionalidade. Na verdade, foi esse modo de controle simplesmente visto como uma técnica para acelerá-lo em determinados casos especiais. Ou excepcionais, poder-se-ia dizer, eis que o ProcuradorGeral da República não seria, como não foi, inclinado a impugnar a inconstitucionalidade, em tese, de norma que não preocupasse o Executivo federal.

24. Vale assinalar que, por via de interpretação, o Supremo Tribunal Federal entendeu dispensada a suspensão da eficácia da norma declarada inconstitucional no controle in abstracto. A sua decisão tem aí eficácia erga omnes e importa, portanto, na perda da eficácia da regra. Em consequiência, nesse caso, não comunica ele a decisão ao Senado Federal, que assim não vem a determinar essa suspensão.

25. Substancialmente, nada mudou quanto ao controle de constitucionalidade na Constituição de 1967 ou na Emenda no 1/69. Nestas, continuaram a coexistir o controle incidental, com o controle principal (este reservado à iniciativa do Procurador-Geral da República).

\section{VI. $O$ controle de constitucionalidade na Constituição de 5 de outubro de 1988}

26. A Constituição de 1988 , no texto promulgado, pouco mudou quanto ao controle de constitucionalidade.

Inovou, todavia, em dois pontos.

O primeiro foi dar a legitimação para a ação direta de inconstitucionalidade a várias autoridades e entidades, a saber I — o Presidente da República; II - a Mesa do Senado Federal; III - a Mesa da Câmara dos Deputados; IV - a Mesa de Assembléia Legislativa; V - o Governador de Estado; IV - a Mesa de Assembléia Legislativa; V - o Governador de Estado; VI — o Procurador-Geral da República; VII — o Conselho Federal da Ordem dos Advogados do Brasil; VIII - partido político com representação no Congresso Nacional; IX - confederação sindical ou entidade de classe de âmbito nacional (art. 103).

Deste rol já se pode induzir o reconhecimento do caráter político de tal controle, pois a entes essencialmente políticos ela fica aberto. Não é este o caso, por exemplo, de "partido político com representação no Congresso Nacional" (inciso VIII)? Supor que partido haverá de ingressar em juízo simplesmente para defender a pureza da ordem constitucional é não compreender a sua índole natural.

O mesmo se diga a respeito de confederação sindical ou entidade de classe de âmbito nacional. Aliás, interpretando restritivamente este dispositivo, o Supremo Tribunal Federal veio a entender que a legitimação de tais entes somente cabe em matéria pertinente a seus interesses, ou, no máximo, de seus filiados.

27. Ademais instituiu a Constituição, e em termos largos, a ação direta de inconstitucionalidade por omissão (art. 103, § 29). Ipsis litteris:

“ $\S 2^{Q}$ - Declarada a inconstitucionalidade por omissão de medida para tornar efetiva norma constitucional, será dada ciência ao Poder competente para a adoção das providências necessárias e, em se tratando de órgão administrativo, para fazê-lo em trinta dias." 
Já se apontou mais acima por que a ação de inconstitucionalidade por omissão é nítida e objetivamente um ato político. E isto ainda é menos evidente no que toca à mera regulamentação de preceito programático da Constituição, do que no concernente à ação administrativa.

A omissão administrativa envolve, muitíssimas vezes, não realizar ações concretas determinadas pela Constituição, ou decorrentes desta. Por isso, importa em providências materiais. Ora, reconhecendo a omissão e dando o prazo de trinta dias para colmatá-la, está o Tribunal impondo uma obrigação de fazer à Administração Pública que pressupõe um juízo de oportunidade (e de possibilidade). Do contrário, se a obrigação for cegamente impostas, desconhecendo-se a possibilidade (inclusive a disponibilidade de meios), a determinação será absurda e vazia: ad impossibilia nemo tenetur.

28. A seu turno, a Emenda Constitucional $\mathrm{n}^{\circledR} 3$, de 17 de março de 1993, instituiu a ação direta de constitucionalidade ${ }^{11}$. Incluiu ela dois parágrafos no art. 103 da Lei Magna, remunerando-o:

" $\S 2^{\circ}$ As decisões definitivas de mérito, proferidas pelo Supremo Tribunal Federal, nas ações declaratórias de constitucionalidade de lei ou ato normativo federal, produzirão eficácia contra todos e eficácia vinculante, relativamente aos demais órgãos do Poder Judiciário e ao Poder Executivo.

$\S 4^{2} \mathrm{~A}$ ação declaratória de constitucionalidade poderá ser proposta pelo Presidente da República, pela Mesa do Senado Federal, pela Mesa da Câmara dos Deputados ou pelo Procurador-Geral da República."

É flagrante que atribuir ao Supremo Tribunal Federal, a função de declarar, in abstracto, a constitucionalidade de uma norma ou de um ato qualquer importa nitidamente em dar ele o papel de terceira Câmara (de função jurídica) do Legislativo ${ }^{12}$. Atribuir-lhe um papel político, portanto.

Trata-se ademais de uma "ação" não contenciosa, o que repugna à tradição do direito brasileiro, pois, neste, ação sempre presumiu lide. É assim que foi interpretada pelo Supremo Tribunal Federal que a admitiu como uma "ação" sem pólo passivo e sem contraditório. Isto reforça o entendimento de que se trata de uma atribuição política, de natureza legislativa, apenas disfarçada de ação, que se conferiu a tal Corte.

Por outra, o texto acrescido atribui à decisão tomada eficácia para todos, o que não surpreende. O que chama atenção - e é sinal dos tempos - está na previsão do efeito vinculante dessas decisões, quer para os demais órgãos do Judiciário, quer para os do Executivo. Decorre da própria lógica de uma decisão com eficácia erga omnes - para nem se dizer que se trata de uma decisão da mais alta Corte do país

11 V. a este respeito o livro Ação declaratória de constitucionalidade, coordenado por Ives Gandra da Silva Martins e Gilmar Ferreira Mendes, Saraiva, São Paulo, 1994, que contém os votos de Ministros do Supremo Tribunal Federal, na ação declaratória de constitucionalidade $n^{\mathfrak{2}} 1-1 \mathrm{DF}$.

12 Mais moderadamente há os que vêem nessa ação de constitucionalidade uma anômala forma de controle prévio. 
- que todos os tribunais e órgãos da Administração estão adstritos a observá-la. Sentir a necessidade de inscrever tal determinação na Lei Magna traduz uma triste perda de autoridade.

\section{A regulamentação legal da ação direta}

29. A Lei no 9.868 , de 10 de novembro de 1999 , veio regulamentar a ação direta, quer de inconstitucionalidade, quer de constitucionalidade.

Nela salta aos olhos uma inovação. A Constituição não inclui entre os legitimados para tais ações nem o Governador do Distrito Federal, nem a Mesa de sua Câmara Legislativa. Ora, a Lei o faz art. $2^{2}$, IV e V. Será isto constitucional?

30. Por outro lado, afora regras procedimentais, sem dúvida importantes, mas que não importam para este trabalho, saliente-se o disposto nos artigos 27 e 28 , parágrafo único, pois, tocam o cerne do sistema constitucional. Examinem-se os mesmos pelo que significam em si mesmos, objetivamente, deixando de lado considerações acerca de conveniência ou inconveniência.

31. Dispõe o primeiro deles:

"Art. 27. Ao declarar a inconstitucionalidade de lei ou ato normativo, e tendo em vista razões de segurança jurídica ou de excepcional interesse social, poderá o Supremo Tribunal Federal, por maioria de dois terços de seus membros, restringir os efeitos daquela declaração ou decidir que ela só tenha eficácia a partir de seu trânsito em julgado ou de outro momento que venha a ser fixado."

Deste texto devem-se destacar alguns pontos de grande alcance.

32. O primeiro, inegável, consiste em registrar que o ato inconstitucional não é mais, como ensinavam doutrina e jurisprudência, nulo e írrito.

É contra a índole do direito admitir que um ato nulo somente possa deixar de produzir efeitos "a partir do ... trânsito em julgado ou de outro momento que venha a ser fixado".

Conclusão óbvia, a violação da Constituição pode ser "direito" positivo, mesmo depois de reconhecida, no processo competente, pelo Supremo Tribunal Federal, "guarda da Constituição".

E, mais. A decisão pode "restringir" os seus efeitos... Isto significa, por exemplo, que ela poderá considerar válidos atos inconstitucionais, ou dispensar o Estado de devolver o que percebeu em razão de tributo inconstitucionalmente estabelecido e cobrado... Donde resultará a inutilidade do controle.

Não é mais rígida a Constituição brasileira.

33. O segundo, patente, registra que não se pode mais considerar declaratória a natureza da ação direta de inconstitucionalidade, mas sim constitutiva-negativa, para empregar a lição de Pontes de Miranda. Sim, porque a decisão não irá apenas declarar um fato - estar a lei viciada de inconstitucionalidade - mas irá desconstituí-la, neste ou naqueles termos.

Disto resulta um problema. É compatível essa formulação com uma ação “declaratória" de constitucionalidade? Não se olvide que a ação de constitucionalidade é expressamente designada como declaratória (Constituição, art. 101, I, “a”). 
34. O terceiro, insofismável, mostra que o controle de constitucionalidade assumiu um caráter político e que nele se pretende que o Supremo Tribunal Federal atue como órgão político.

Senão, veja-se.

A atribuição de eficácia ex nunc ou a partir de um determinado momento à decisão que reconhece a inconstitucionalidade pressupõe duas condições: uma, for$\mathrm{mal}$, ser tomada pelo quorum de dois terços do Ministros do Supremo Tribunal Federal; outra, material, ocorreram "razões de segurança ou de excepcional interesse social".

A última é incontestavelmente uma apreciação de conveniência e oportunidade - de mérito, no sentido administrativo do termo. É uma apreciação tipicamente política. E subjetiva, porque admitir que haja razões de segurança, ou de interesse social, qualificado de excepcional, depende da visão que cada um tenha das coisas.

Que se trata de uma apreciação política é tese reforçada pela exigência de quorum para tanto. Está nisto - é certo - uma cautela, mas esta cautela adverte para o risco de ... se verem motivos de segurança ou de interesse social, onde muitos não as veriam... No mesmo sentido, milita a previsão, no art. $10, \S 3^{\circ}$ da citada Lei da publicação no Diário Oficial da parte dispositiva da decisão, a fim de ensejar a eficácia contra todos e o efeito vinculante.

Disto tudo decorre, mais uma vez, a conclusão de que o Supremo Tribunal se torna uma terceira Câmara do Poder Legislativo.

35. Reforça este entendimento o disposto no art. 28, caput, que manda publicar no Diário Oficial a parte dispositiva da decisão, como condição do efeito vinculante e da eficácia contra todos.

Considere-se agora o parágrafo único do art. 28:

"A declaração de constitucionalidade ou de inconstitucionalidade, inclusive a interpretação conforme $a^{13}$ Constituição e a declaração parcial de inconstitucionalidade sem redução de texto, têm eficácia contra todos e efeito vinculante em relação aos órgãos do Poder Judiciário e à Administração Pública federal, estadual e municipal."

Cabe aqui lembrar que esse texto se inclui num capítulo que regula a "decisão na ação direta de inconstitucionalidade e na ação declaratória de constitucionalidade". Entretanto, o art. 102, $\S 2^{\circ}$ (com a redação da Emenda $n^{\circ} 3 / 93$ ) apenas admite a eficácia contra todos e efeito vinculante nas ações declaratórias de constitucionalidade, não nas ações diretas de constitucionalidade. Manda, por isso, uma interpretação conforme a Constituição que essa regra somente se aplique às referidas ações declaratórias de constitucionalidade.

Registre-se, por outro lado, que este texto reconhece a jurisprudência do Supremo Tribunal Federal quanto aos efeitos da decisão no caso de ação direta, no sentido de dispensar a suspensão da execução pelo Senado Federal.

Igualmente, vale consignar que consagra a "interpretação conforme à Constituição" adotada pela mesma jurisprudência, inspirada na da Corte alemã. Na verdade,

No texto oficial, publicado no D.O.U., inexiste crase. 
esta, sem o dizer, eqüivale à decisão na representação interpretativa que previa o direito constitucional anterior (Emenda Constitucional $n^{2} 1 / 69$, art. 119, I, " 1 ").

36. Note-se, enfim, que a Lei abre a possibilidade de uma dilação probatória (art. $9^{\circ}, \S 1^{\circ}$ ). Isto certamente ensejará figura, não do assistente, mas a do amicus curiae.

VIII. A regulamentação da "argüição de descumprimento de preceito fundamental" decorrente da Constituição

37. A previsão desta argüição, presente desde a redação primitiva da Lei Magna, e, depois da Emenda $\mathrm{n}^{\circledR} 3 / 93$, art. 102, § $1^{2}$, sempre deixou intrigados os estudiosos.

As razões disto são fáceis de compreender. Uma é dar a entender que na Constituição há normas fundamentais e normas não fundamentais. Ora, disto se pode extrair a idéia de que há uma diferença entre estas no seu status, o que contraria a doutrina tradicional, pacífica, de todas as regras constitucionais são igualmente cogentes.

A segunda que o descumprimento de preceito constitucional, seja fundamental ou não, tem na ação direta de inconstitucionalidade comum e na por omissão o meio de correção, do que resultaria ser inútil tal "argüição".

38. A Lei $\mathrm{n}^{2} 9.882$, de 3 de dezembro de 1999 , regulamenta e para tanto interpreta o preceito constitucional. Dá-lhe como objeto "evitar ou reparar lesão a preceito constitucional" (art. $\mathbf{1}^{\mathbf{9}}$ ).

Vale transcrever alguns preceitos que edita, essenciais para o desenho de seu perfil. A saber:

1) São legitimados para propô-la apenas os legitimados para a ação direta de inconstitucionalidade (art. $2^{\circ}$, I). De fato, foi vetado o inciso II que estendia a outros essa legitimação ${ }^{14}$. Surge, todavia, uma dúvida, no que toca ao Governador do Distrito Federal e da Mesa da Câmara Legislativa distrital, não legitimados no texto constitucional, conquanto o estejam na Lei reguladora das ações diretas;

2) Da inicial deve constar:

"Se for o caso", a comprovação da existência de controvérsia judicial relevante sobre a aplicação do preceito fundamental que se considera violado" (art. 3, V);

3) Entretanto:

"Não será admitida argüição de descumprimento de preceito fundamental quando houver qualquer outro meio eficaz de sanar a lesividade" (art. $\left.4^{\circ}, \S 1^{\circ}\right)$;

4) Caberá liminar nessa ação, desde que deliberada pela maioria absoluta dos membros do Supremo Tribunal Federal (art. 5o, caput).

"A liminar poderá consistir na determinação de que juízes e tribunais suspendam o andamento de processo ou os efeitos de decisões judiciais, ou de qualquer outra

14 Assinale-se uma incongruência do texto promulgado. $\mathrm{O}$ inciso II do art. $2^{\alpha}$ foi integralmente vetado, mas se manteve o $\S 1^{2}$ desse artigo, que regula o inciso Il.... 
medida apresente relação com a matéria objeto da argüição, salvo se decorrentes da coisa julgada" (art. 5o, § $3^{\mathrm{o}}$ );

5) A decisão importaria em fixar para as "autoridades e órgãos responsáveis pela prática dos atos questionados" não só "o modo de interpretação" como o de "aplicação do preceito fundamental" (art. 10);

6) A decisão terá eficácia contra todos, bem como efeito vinculante (art. 10, $\left.3^{\circ}\right)$.

7) O Supremo Tribunal Federal:

"Ao declarar a inconstitucionalidade de lei ou ato normativo... tendo em vista razões de segurança jurídica e de excepcional interesse social, poderá, por maioria de dois terços de seus membros, restringir os efeitos daquela declaração ou decidir que ela só tenha eficácia a partir de seu trânsito em julgado ou de outro momento que venha a ser fixado" (art. 11).

Acrescente-se que, seguindo o disposto para as ações diretas, a Lei abre campo para uma dilação probatória.

39. A simples leitura dos pontos acima assinalados já mostra a importância, mais do que isto, a gravidade do que decorre desta Lei.

O primeiro ponto a ressaltar é que ela foge à caracterização do que seja "preceito fundamental", o que é compreensível. Implicitamente ela admite que toda norma constitucional é "preceito fundamental" e conseqüentemente seja discutida na argüição.

Disto resulta ser ela uma nova ação direta de inconstitucionalidade, com outro nome.

40. Entretanto, seu objetivo real, disfarçado embora, é introduzir uma forma de avocatória, concentrando nas mãos do Supremo Tribunal Federal questões de inconstitucionalidade, suscitadas incidentalmente perante outras instâncias.

De fato, a arguiição traz a matéria para o juízo do Supremo Tribunal Federal, enquanto a liminar nela concedida pode suspender "o andamento de processo ou o efeito de decisões judiciais, ou de qualquer outra medida que apresente relação com a matéria objeto" da mesma (art. $5^{\ominus}, \S 3^{\circ}$ ).

Ora, quando decidida pelo Supremo Tribunal Federal essa argüição, o entendimento deste se torna obrigatório para todas as autoridades, judiciais ou não, pois terá eficácia contra todos e efeito vinculante (art. 10, caput, e especialmente $\S 3^{\circ}$ ).

Isto significa que, a requerimento de um dos legitimados para a ação - o Presidente da República ou o Procurador-Geral da República, por exemplo - todos os processos que versarem uma determinada questão constitucional - aqueles em que se impugne a constitucionalidade de um tributo, verbi gratia - poderão vir a ter a sua tramitação sustada, até que o Supremo Tribunal Federal aprecie o tema, embora in abstracto.

A decisão do Supremo - enfatize-se - fixará o entendimento sobre o ponto, seja pela constitucionalidade, seja pela inconstitucionalidade, e, como terá "eficácia contra todos e efeito vinculante", o mesmo será obrigatório para as autoridades e órgãos que tiverem de enfrentá-lo, como premissa de alguma decisão, judicial ou administrativa. 
Note-se que, como se dá em relação às ações diretas, o efeito vinculante e a eficácia contra todos estão condicionadas à publicação da parte dispositiva da decisão (art. $10, \S \S 2^{\circ}$ e $3^{\circ}$.)

41. Quanto a esta "eficácia contra todos e efeito vinculante", o legislador foi certamente além do que permite a Constituição vigente.

Lembre-se que o art. 102, $\S 3^{o}$ da Lei Magna não concede esse alcance senão às "ações declaratórias de constitucionalidade de lei ou ato normativo federal". Certamente não o faz quanto a arguiições de descumprimento de preceito fundamental.

42. Note-se, enfim, que essa argüição pode versar controvérsia acerca da constitucionalidade, em face da Lei Magna federal, de preceito municipal (art. $1^{9}$, parágrafo único, I).

Insinua-se, deste modo, o que sempre o Supremo Tribunal Federal recusou, ou seja, a possibilidade de examinar ele a adequação à Constituição brasileira das normas municipais, em ação direta.

\section{Observações finais}

43. Da análise feita, alguns pontos devem ressaltados.

A primeira é que o sistema de controle de constitucionalidade previsto no direitu constitucional brasileiro se torna cada mais complexo. Ao controle incidental já se acrescentara ação direta de inconstitucionalidade, de inconstitucionalidade por omissão, de constitucionalidade e agora a argüição de descumprimento de preceito fundamental. Isto, contudo, não significa haver ele se tornado mais eficaz.

44. A grande verdade é que a eficácia real do controle depende antes de tudo da rapidez com que o Supremo Tribunal Federal possa manifestar-se. Dado o acúmulo de questões que o assoberbam, inclusive de ações diretas de inconstitucionalidade, este não dá conta do serviço. A duras penas aprecia os pedidos de liminar, deixando para as calendas gregas a apreciação do mérito (mesmo quando declara que a matéria seria mais aprofundamente examinada nessa ocasião).

Solução para isto não virá, em termos realistas, enquanto esse Tribunal não tiver mudada a sua competência para que fique apenas como "guarda da Constituição". Ou, caso se crie uma Corte constitucional especializada, que poderia desdobrar-se em seções especializadas no controle de constitucionalidade, uma, de leis e atos normativos federais, outra, de Constituições, leis e atos normativos estaduais em face da Lei Magna brasileira. E, quiçá, uma terceira, realizando o desejável controle de constitucionalidade de leis orgânicas e de leis e atos normativos municipais, em contraste com a Carta federal. Isto evidentemente não excluiria que os Estados tivessem as suas próprias Corte, ou deixassem a tarefa de conferir a constitucionalidade de leis e atos normativos estaduais ou municipais perante a Constituição estadual a seus próprios Tribunais de Justiça. 
45. Acrescente-se que as inovações quanto aos efeitos do ato reconhecido como inconstitucional não tornam mais vigorosa a defesa da Constituição. Ao contrário, elas provavelmente a enfraquecem. $O$ ato inconstitucional não é mais nulo ex natura... Seus efeitos poderão persistir mesmo depois de reconhecimento a infração à Constituição; ele poderá persistir como norma obrigatória depois deste reconhecimento ${ }^{15} \ldots$ Ou seja, o ato inconstitucional ganha uma sobrevida que significa em termos crus que modifica, ou modificou a Constituição, pelo tempo em que foi tolerado.

46. Nitidamente, por outro lado, o controle se politiza, pois, não mais se põe como uma verificação de supralegalidade e mas tende a se tornar um controle de legitimidade. O Supremo Tribunal Federal assume cada vez mais o papel de terceira Câmara do Legislativo. Passa a ser como que uma supercomissão deste encarregada de examinar a constitucionalidade de atos normativos...

De fato, ela não declara simplesmente o vício de inconstitucionalidade que macula um ato; ele o desconstitui a partir do instante que isso lhe parecer oportuno e conveniente. Sutil é a diferença entre isto e uma revogação...

Esta tendência à politização já está bem marcada - reconheça-se - na Constituição em vigor, como já assinalei noutro trabalho, "O Poder Judiciário na Constituição de 1988 - Judicialização da política e politização da Justiça" ${ }^{16}$. Conviria, porém, avaliar mais detidamente as consequiências disto.

E especialmente conviria examinar se não seria de bom alvitre especializar o controle, atribuindo-o a uma Corte, como acima já se apontou. Esta poderia até desempenhar um controle preventivo.

Isto forneceria o elemento de legitimidade democrática que certamente não possui o Judiciário, Poder cujos membros são escolhidos por um método "aristocrático" de seleção, mas sim por concurso ou por escolha por autoridade política.

47. É curioso que num país em que a imitação do estrangeiro é princípio de política legislativa, em nome da imperiosa necessidade de seguir os "avanços"... o que se passe com o controle de constitucionalidade é um bom exemplo disto não se tenha cogitado de substituir o complexo sistema adotado por outro que é simples e eficiente: o controle preventivo. Seguindo-se nisto, ou não, o modelo francês.

Antes da edição do ato normativo uma Corte constitucional faria o controle, impondo a adaptação da proposta às normas fundamentais. Isto, por iniciativa do autor da proposta ou de qualquer das Câmaras, ou de uma parcela ponderável de seus membros.

Assim as regras a final editadas seriam sempre constitucionais, ou teriam de ser consideradas como tais, sem possibilidade de contestação. Desapareceria, destarte,

15 É certo que a própria constitucionalidade das inovações será discutida, mas provavelmente serão elas admitidas como válidas pelo Supremo Tribunal Federal, pois lhe aumentam o poder ou lhe reduzem a carga.

16 RDA 198/1. 
a polêmica sobre a sua validade, portanto, a incerteza quanto ao Direito, que não só gera inúmeros litígios como abala a segurança jurídica.

Dir-se-á que isto não atenderia à premência de tempo na elaboração das leis; nisto, haveria outra vantagem: menos leis. Surgiria um freio à inflação legislativa, tão negativa e prejudicial quanto a monetária.

Não é por falta de leis que o país não é bem governado! 


\section{Direitos Humanos e Conflitos Armados}

Celso D. de Albuquerque Mello

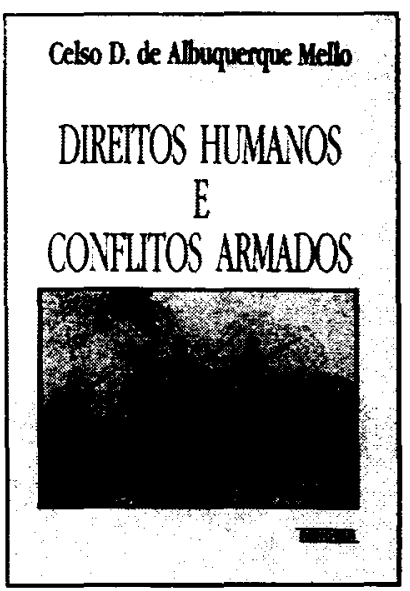

O DI Humanitário é um complemento dos D. Humanos e forma com este o DI dos Direitos Humanos em sentido amplo. É um tema que interessa a todos que vivem neste final do milênio. $\hat{E}$ preciso difundir, no Brasil, a noção de direitos humanos.

Ref. 0148

Form. 16x23

Brochura

1997

500 págs.

\section{Divórcio e Separação Judicial Áurea Pimentel Pereira}

Esta obra é de grande utilidade para os profissionais e interessados em Direito de Família. A autora, em linguagem clara, comenta, artigo por artigo, a Lei do Divórcio, apontando suas alteraçōes decorrentes da Constituição de 1988. Os aspectos controvertidos sāo abordados, com especial cuidado, unindo a longa experiência da autora, que muitas vezes diverge de outros comentadores, mas justifica seu entendimento e cita doutrina e jurisprudência, inclusive de direito comparado.

Ref. 0013

Form. 14x21
Brochura 1998
216 págs. $9^{3}$ ed.

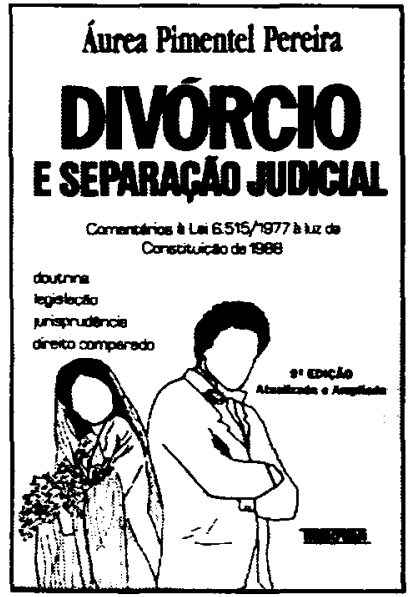

